\title{
Survive and Persist: Amherst and Classical College Development during the Age of American University Proliferation
}

\author{
Matthew R. Hodgman \\ Dept. of General Education, Goodwin College \\ 1 Riverside Drive, East Hartford, CT, 06118, USA \\ Tel: 1-860-528-4111Ｅ-mail: mhodgman@goodwin.edu
}

Received: Oct. 13, 2013 Accepted: October 29, 2013 Published: November 1, 2013

doi:10.5296/jse.v3i4.4417

URL: http://dx.doi.org/10.5296/jse.v3i4.4417

\begin{abstract}
Throughout American history, institutions of higher education have faced difficult decisions relative to institutional survival, direction, and long-term relevance within a constantly changing and evolving higher education landscape. History has shown us that successive generations have had a significant and unique impact on the higher education landscape. The survival and flourishing of classical liberal arts colleges during the rise of universities during late $19^{\text {th }}$ century America marks an important moment in the history of higher education. This article will attempt to position the institutional developments of Amherst College within the context of Roger L. Geiger's “The Ten Generations of American Higher Education” and simultaneously demonstrate the unwavering and remarkably durable institutional spirit that contributed to the survival of Amherst during the progressive rise and development of universities in America. Amherst's survival and subsequent success is an example of how an educational institution can position itself for enduring success during a monumental change to the larger educational landscape.
\end{abstract}

Keywords: Amherst College, Higher Education, Classical Colleges, Roger L. Geiger, History of Education 


\section{Introduction}

This article will attempt to situate the institutional developments of Amherst College within the context of Roger L. Geiger's “The Ten Generations of American Higher Education” and in doing so illustrate the steadfast and resilient institutional spirit that contributed to the survival of Amherst during the progressive rise and development of universities in America. In many respects, Amherst's survival and subsequent success is an example of how an educational institution can position itself for enduring success during a monumental change to the larger educational landscape.

Geiger (2005) reductively posits that we study the history of higher education because "things change and because some things do not change" (p. 38). As change is inevitable and well-suited to temporal analysis we must strive to understand the processes of change and group change dimensions in a way that meaningfully distinguishes fundamental transformations in the entire higher education landscape. Geiger has accomplished this by capturing the generational shifts in higher education in ten approximate thirty year spans. These ten generations are explained in terms of curriculum, student experiences, stakeholder interventions, structural advancements, and a litany of other institutional developments. The heuristic nature of Geiger's generations allows for individual institutional analyses in terms of monitoring change and generally making sense of the idiosyncratic origins, developments, and value-systems of colleges and universities within larger discursive movements of the day. Indeed tracing an institution through the ten generations is akin to placing the remaining puzzle pieces in the middle of a puzzle where the outside frame or edges have already been put in place.

\section{Amherst College and Geiger's Ten Generations of American Higher Education}

As a college that originated in generation 5 (the classical, denominational period from the 1820s-1850s) Amherst mainly evidenced the predominant overlapping characteristics of classical, denominational colleges (CDCs) as articulated by the Lutherans of present-day Gettysburg College as students, teachers, and trustees were church members; in a certain sense it is fair to say that the college "belonged to the church" (Geiger, 2005, p. 49). However, while Amherst may at times fit neatly beneath the epithets attached to Geiger's successive generations, the college has also embodied noteworthy deviations (in birth, governance, progressivity etc.) from the "typical" classical, denominational mold and these anomalies will be accentuated throughout this analysis.

Before jumping to the generation of Amherst's origin, it is important to explain the historical context prior to the college's founding; Geiger's generations 3 and 4 (Republican Education, The Passing of Republican Education, 1776-1820s) precede Amherst's founding but give an appropriate context from which to understand the overall climate at the time of the founding. The classical curriculum of Latin, Greek, rhetoric, philosophy, logic etc. was brought from abroad as were ideas of effective religious control, collegiate residential living, aristocratic student bodies, and an emphasis on teaching, students, order, and discipline over study, and learning (Rudolph, 1991, p. 26). The colonial context stressed the importance of hierarchy and English loyalty. 
With revolution came an inevitably new zeitgeist steeped in forging and emphasizing differences between colonial needs and aspirations and what England expected colonists to be (Rudolph, 1991, p. 33). As symbols of English control, American colleges were the targets of revolution-spirited destruction as exemplified by the carnage inflicted on Princeton's Nassau Hall and the campuses of King's College and William and Mary respectively. The fight for independence was also a movement toward democracy and many colleges were erected from revolutionary sentiment as denominational rivalry, state loyalty, increasing wealth, and growing population undergirded an unchecked collegiate growth into the nineteenth century. Colleges were now carrying out a new responsibility to a new nation where responsible citizens would be cultivated and encouraged to lead useful lives in the defining of a new republic (Rudolph, 1991, p. 36).

In the $18^{\text {th }}$ century, colleges continued to be shaped by the Enlightenment as they embraced the use of reason as a means to reform society. Science and intellectual exchange triumphed over superstition and intolerance as scientific methods and results increasingly informed and expanded knowledge. At institutions such as the College of Philadelphia an enlightened curriculum with English literature and civics was emerging. In combination with the momentum and spirit induced by revolution, Enlightenment beliefs contributed to the belief that science, democratic participation, and universal knowledge were key elements in refashioning the nature of authority, culture, and indeed the entire social order in the new republic. The Republican universities would emphasize science and downplay Greek and Latin. They would accentuate the optimistic and forward-looking ideals and manners of the new republic namely: virtue, gratitude, tolerance, honesty, sincerity, civility, tabula rasa, liberty, freedom, civilization, refinement, and politeness. A "gentleman” would be defined as one who embodied these characteristics of a republican liberal arts education (Wood, 1993, p. 195). The colonists were creating a society where gentility could be learned instead of bestowed upon one by birth. Although the importance of republican ideals and of their transmission through colleges were paramount to the time, republican higher education would wane in the face of resource and faculty shortages, a new democratic-republican political alignment, and an overall lack of demand.

The new democratic-republican powers ushered in attacks on privilege and elitism as a desire to valorize the "common man" took its place. The republican emphasis on discipline and order was wearing thin on students. Questions surrounding the ownership, mission, curriculum and discipline structures of colleges became more salient in the early $19^{\text {th }}$ century and accordingly student acts of resistance to college authority permeated college campuses. Student riots were interpreted as a contributing reason behind a curricular shift back toward the "safe" comforts of Latin and Greek (Geiger, 2005, p.45). As the links between professional education and colleges were dissipating, the preparation of ministers became the focus of burgeoning provincial institutions and grew in alternative to a collegiate education. The ruling in the Dartmouth College court case (1819) protected colleges from legislative intrusion, thus establishing an agenda of privatization that would pave the way for unambiguously private classical, denominational colleges (Geiger, 2005, p. 47). 


\subsection{Generation 5}

Enter generation 5, the era of classical denominational colleges from the 1820s to the 1850s. Amherst emerged during a time where the nation was rapidly expanding and religious denominations held powerful economic resources endemic to founding a college. Remnants of the revolution and prior wars with Native American habitants of present-day New England were still felt in the early 1800s. Surrounding Hampshire County towns including Hatfield, Deerfield, Northampton, and Northfield were the site of brutal battles associated with King Philip's War which destroyed the area physically and economically. If there was one positive takeaway from King Philips's and from the Revolution it was that a distinct American identity was emerging apart from the English Crown, one that was not afraid of sacrifice and struggle (Tyler, 1873, pp. 18-22).

The founding of Amherst was first formally conceived at a meeting of the Franklin County Association of Ministers in 1815. At this meeting, the ministers along with members of Amherst Academy, and motivated townspeople considered the many benefits of establishing a college in the area. The desire of the ministers was to found an institution for the "education of indigent young men of piety and talents for the Christian ministry" (Amherst College). The religious context behind the founding of colleges was well-established during this generation (Geiger, 2000, p. 21). The most prominent advantages of founding a college in Hampshire County Massachusetts during the early 1800s included: geographical beauty in a well-populated area; a central location to other colleges; fertile land; an intelligent and pious local population; and a local secondary school (Amherst Academy) which would help the college cultivate science and literature (Tyler, 1873). The ministers worked with the administration of Amherst Academy and with a wide array of local stakeholders to establish the economic feasibility of the college. In 1817 a project was adopted to raise funds for what would become the college. A concerted enterprise between the citizens of Amherst, academy officials, and ministers allowed for a \$50,000 “Charity fund" to be raised which would financially support the indigent students who enrolled (Tyler, 1873, p. 27). Even when this fund dipped below the stated amount in the early years of the college, local citizens and stakeholders (some of which who were not religiously focused) provided monies to sustain the fund (Hitchcock, 1863, pp. 120-121). While Geiger's claim that CDCs were established by religious minorities in an attempt to provide churches with institutions that fully belonged to them is basically a truism, it would be incomplete to think of Amherst solely as a belonging to the ministry (Geiger, 2005, p. 49). The school was very much the progeny of Amherst Academy as well as a very dedicated citizenry who enthusiastically supported both the religious goals and secular benefits that would ensue. Denominational efforts certainly made up for a lack of financial backing from the state, but ministers were not the only financial and emotional champions of the college.

Despite this fertile environment for the creation of a new college, there were very real ideological and political challenges to the founding of Amherst. One challenge to overcome was the general criticism of CDCs in the 1820s. New colleges such as Amherst were attacked for their overdependence on Latin and Greek, for neglecting practical science, and for the unruliness of seemingly disgruntled students (Geiger, 2005, p. 48). The first two of these "inadequacies" were challenged by the Yale Report of 1828 which staunchly defended the 
classical curriculum as the best way to lay the foundation of a "superior" education by disciplining the mind and secondarily providing it with content or "furniture" (Geiger, 2005, p. 48). Thus, a classical curriculum helped students develop proper culture and correct taste. The Yale Report was wildly influential thus paving the way for Amherst to continue its classical course.

Other early struggles faced by the college surrounded its actual founding and the securing of a charter. Opposition to the founding came from churches and perishes in surrounding towns such as Northampton where citizens felt a college should be built in their district. Harvard loyalists were averse to the idea of another potentially powerful institution in the area and attempted to block the granting of a charter to Amherst. In addition, there was talk of moving Williams College to Amherst which would have dampened any chance for a completely new college in Hampshire County. Luckily for the town of Amherst, these opposing forces did not win out and Amherst was awarded a charter on the $21^{\text {st }}$ of February, 1825.

As pointed out by Thelin (2011) the classical denominational generation was a period of extreme innovation and consumerism where government regulation was non-existent yet it was not a period of chaos for higher education (p. 41). This fact is a testament to the resourcefulness, innovation, and variety that defined CDCs in the first half of the nineteenth century. Colleges during this era differed along regional and curricular lines. The college building boom during this time brought the world colleges with varying purposes and values. For example, South Carolina College embodied the regional values of a plantation aristocracy where administrators hoped to develop local scions for positions of leadership (Thelin, 2011, p. 48). In addition, Transylvania University in Virginia offered curricular innovations by adding sciences such as botany to the course and maintained flourishing law and medical schools (Thelin, 2011, p. 46). Despite traditional claims that CDCs were impractical and unpopular, these colleges were growing and serving local communities through expansion and elaboration patterns where they became increasingly established in frontier lands and found ways to serve their respective minority religious interests (Geiger, 2000, p. 22). It seems fair to say that traditional views of CDCs were based on incomplete data and necessarily undervalued the resourceful concerted efforts these schools employed to remain relevant to their locales (Geiger, 2000; Potts, 1981; Thelin, 2011). Amherst in particular saw its enrollment numbers steadily increase during its initial years and like other "hilltop colleges” in New England, was connected to its regional economy and demography by providing opportunities to sons of local farm families who otherwise would have had "no prospects” (Thelin, 2011, p. 53). Although Amherst did not implement stark curricular reforms like Transylvania, it was a resourceful school that gave local non-traditional indigent youth opportunities for self-improvement in ministerial and teaching fields. The charity fund at Amherst assured indigent youth that their studies would be free to them. It seemed like a win-win situation for students so why was there initial student unrest in so many CDCs?

Although CDCs originated in a generation where America was becoming an increasingly democratic and egalitarian society, colleges still embodied the republican ideals of hierarchy and authority (Geiger, 2000, p. 11). This rigid social structure in combination with the relative youth of students and an increasingly wealthy student body who did not share the pious outlook of the administration was a mixture for social unrest on campus (Geiger, 2000, 
p. 11). Indeed the "collegiate way," or the notion that a curriculum, library, faculty, and students are not enough to make a college, often permeated college campuses in the form of a suffocating paternalism (Rudolph, 1991, p. 87). Although proponents agreed that collegiate paternalism would help students develop higher aims and better tastes, reformers contended that the collegiate way reflected a misuse of administrative guidance where spoon-feeding and hand-holding would stifle student creation and prolong adolescence unnecessarily (Rudolph, 1991, p. 108). Students at Amherst were not immune to the collegiate way. For example, the observance of study hours was enforced with much strictness by the college and fines were liberally assessed to students who failed to use study hours "properly" or for other reasons such as playing musical instruments or attending the village church without permission (Tyler, 1873, pp. 187-188). Stringent codes such as these triggered riot conditions on campus. Non-rioting students at Amherst were concerned with the lack of safety on their campus and organized a government for ensuring order called the "House of Students" (Amherst College). Student revolts and unrest and the apparent lack of effectiveness of a controlling disciplinary regime led to an increase in student freedom and responsibility as students gained greater control over their everyday lives (Geiger, 2000, p. 12). At Amherst as well as other colleges, students used their new-found freedom and increased order on campus to expand their curricular options at the school. In particular, literary societies on campus, specifically the Alexandrian and Athenian societies, dominated campus extracurricular activity. These societies helped students increase skills pertaining to literature and oration. Societies at Amherst proliferated at a swelling pace and included the following sample: the Beethoven Society, Glee Clubs, alumni associations and the Gymnastic society. The gymnastic society in particular was held in high esteem and contributed to health and happiness on campus as it was the result of student desires for more physical activity (Allen, 1869; Ball, 1896; Cutting, 1871). An anti-slavery society stirred controversy and student misconduct on campus (Wilson, 2007, p. 25). Other societies debated whether women should go to college and whether a single-sex environment was more effective than a coeducational one (Wilson, 2007, p. 80). Student sports were burgeoning at mid-century and the first intercollegiate baseball game was played between Amherst and Williams in 1859 (Amherst College).

Despite the uptick in extracurricular activities on campus, CDCs by mid-century were still under attack for their rote classical curricula. As Francis Wayland noted, CDCs focused too narrowly on catering to the professional class and at the expense of practitioners of industry and commerce who were responsible for the changing American economy (Geiger, 2005, p. 51). As the next generation approached, new institutions would establish themselves in complement to staunchly classical colleges such as Amherst.

\subsection{Generation 6}

Generation 6 (1850s-1890) ushered in new departures in higher education. As Geiger (2000) explains, multi-purpose colleges adapted their degree courses to reflect an expanding academic knowledge base and to cater to emerging markets for practical, vocational skills (p. 128). Parallel courses such as the one offered at Union College included substitutions of science or modern languages for Latin and Greek and students were allowed to study subjects 
of their own choosing (Geiger, 2000, p. 139). Multi-purpose schools that were too religious in focus or that failed to offer strong pre-professional preparation died off. The varied multi-purpose curricula did not occur at Amherst as the college held tight to the merits of a classical curriculum as defended by the Yale Report. Multi-purpose colleges expanded their missions to embrace the education of a learned laity and tended to admit women. Although Amherst remained a progressive institution (the school admitted Asian and African American applicants) and expressed interest in admitting "qualified” women, the school would expand its academic offerings to women for another century (Amherst College). Despite no slant toward a multi-purpose curriculum and the unsuccessful application of two women to the college, school spirit and student governance on campus were advancing at Amherst. The school adopted the school colors of mauve and white (which eventually changed to purple and white) and "The Amherst System" was introduced on campus in 1876 which was a progressive, if not revolutionary, system that allowed students to govern their own affairs and decide on disciplinary methods (Amherst College).

Other major developments during this generation included the rise of research universities and land-grant colleges. As extracurricular activities, alumni support, and a preoccupation with social status impacted student life at colleges, universities were structurally growing into the next big thing in higher education. The German model of education found a home in American universities. Thanks to adaptations of Wissenschaft, American universities such as Johns Hopkins and the University of Michigan were developing the synergy between teaching and research. The PhD became linked exclusively to specialized training in original research; indeed, Americans were appropriating the German research ideal and giving it a home in American graduate schools (Turner \& Bernard, 1993, p. 239). There was a developing commitment to the idea that faculty were scholars and researchers instead of mere teachers and tutors.

The idea of "useful knowledge" won the day in the late $19^{\text {th }}$ century. As Geiger (2000) explains, useful knowledge was a set of ideas that looked to education in science to directly enhance the productivity and social standing of mechanics, artisans, or farmers (p. 154). Besides fostering access to useful higher education, the Morrill Land-Grant Act of 1862 polarized farmers and academic specialists (Sorber, 2013). The idea of what was "useful" and to who was at the center of a tenuous debate between farmers and academic ideologues. Farmers desired knowledge that would lead to vocational ends where those in the academy including Daniel Coit Gilman felt that useful knowledge should train specialists in science and math, not workers; it should train managers and scientists to become leading engineers and advance American capitalism (Geiger, 2000, pp. 161-162). The farmers obviously disagreed with Gilman and joined granges to fight the idea that advancing science and the economy should be prioritized over supporting the common man (Sorber, 2013). While the intentions of Morrill were noble, the implementation of the act was far from seamless. States were left to interpret Morrill (as the language of the act did not explicitly define the courses of study a state was to implement) and prior to popular understanding, the act did not create most of the country's state colleges nor did it first establish mechanic and agricultural arts on campus, many were already in place prior to 1862; schools such as the university of Wisconsin already housed practical fields of study and statewide extension (Thelin, 2011, pp. 
76-77). Morrill was an afterthought with respect to higher education, the central question at the heart of Morrill was how to deal with vast expanses of land in the West and to what end (Thelin, 2011, p. 78). The importance of Morrill is that it established "at least one college" in which practical subjects would be taught without excluding other scientific and classical studies (Geiger, 2005, p. 53).

In post-Civil War America, higher education was straddling a significant number of polarities such as the conflict between tradition and modernity, religious and secular forces, localism and nationalism, and institutional authority and academic freedom (Hall, 1982, p. 196). CDCs such as Amherst were caught between competition from high school and American universities. The expansion and elaboration of denominational colleges existed in complement to the development of the great American university. The chief higher educational conundrum of the era was the relationship between graduate education and the American college which would be dealt with more in the next generation (Geiger, 2005, p. 53).

\subsection{Generation 7}

At the beginning of generation 7, there was a crisis of the "old order" of colleges as they had to come to terms with an expanding high school sector and universities who laid claim to "higher education” (Geiger, 2000, p. 265). High schools were resisting college desires for more rigorous academic preparation in Latin and Greek. Liberal arts colleges such as Amherst were finding a new role as sites of preparation for graduate study. Amherst still valorized the classical curriculum but started offering a few practical courses such as a business administration course for all newly admitted students to comply with obstinate high school demands (Levine, 1988, p. 110). Colleges were forced to teach a portion of university academic subjects to compete with universities or perish. Many multi-purpose colleges died off during this time as they did not have the resources to provide pre-professional preparation. Universities had knocked colleges off their perch at the top of the higher education food chain and set the standard for the rest of higher education. Universities became standardized as the creation of a professional bureaucracy on campus took shape. Units in engineering, business, education, and other smaller specialties were added (Geiger, 2005, p. 55). However, colleges were "saved" during this time as professional schools increasingly required college degrees for admission; the undergraduate college was becoming a component of the American university (Geiger, 2000, p. 275). Thus professional schools thrust colleges into the role they always wanted, a pre-professional one. Amherst responded to this new role by trying to convince potential students that it offered an elite education that would increase social standing and perpetuate the social leadership responsibilities of the noblesse oblige (Levine, 1988, pp. 106-107). Amherst's recruitment strategy consisted of preserving the distinct liberal tradition and creating an environment where students would be trained to become the leading professionals and businessmen of their day (Levine, 1988, p. 107). Intellectual development and honors programs were valued on campus in an attempt to preserve elite cultural bastions of culture and influence (Levine, 1988, p. 112). Indeed, liberal arts colleges and the classical curriculum were having a renaissance during this generation but standardization meant that by WW I American colleges and universities mostly 
conformed to a single pattern in terms of admissions, credit hours, offerings, majors etc (Geiger, 2005, p. 57).

\subsection{Generation 8}

Generation 8 in higher education brought with it increasing hierarchical differentiation between the wars. The increasing understanding that college was a means of socioeconomic mobility coincided with the rapid expansion of higher education. Elite patterns of higher education solidified themselves in comparison to mass forms. Elite patterns (such as those found at Amherst) were characterized by full-time residential students, cultural ideals of liberal learning and character formation, and by placing students in high-status professions where mass forms of higher education catered to part-time students and prepared students for technical or semi-professional positions (Geiger, 2005, p. 57). The mass sector grew to contain junior colleges, teachers colleges, and urban service-oriented universities. Socially, despite the growing popularity of colleges and universities, the drop-out rate was high. At Amherst, for example, the graduation rate fell to nearly 50 percent from 75 to 90 percent just ten years earlier (Thelin, 2011, p. 176). The "college ideal" was a source of American celebration and was growing to be a matter of serious social implication, but was basically limited to white males (Thelin, 2011, p. 169). This ideal was a part of the criteria used to claim elite status along with the quality of undergraduate learning and the imperative of advancing knowledge (Geiger, 2005, p. 59). The college ideal was determined by the peer society of students, extracurricular activities, and by expectations of subsequent careers in the business world (Geiger, 2005, p. 59). Indeed America was status-smitten and colleges provided opportunities to raise one's social standing in a relatively short period of time. Amherst was one of the schools that did not choose to pursue a policy of indefinite expansion and instead sought to develop a small, carefully selected student body (Levine, 1988, p. 139). Elite status was an important selling point for small liberal arts colleges that did not have an extensive university curriculum or offer a varied social college experience. Sadly, during this generation, selectivity in college admissions took a negative turn as social class and ethnicity played a large role in college admissions and achievement was often not a central admission criterion; this pattern only perpetuated the white (WASP) hegemonic order (Levine, 1988, p. 136). Amherst did not pursue ethnically, racially, or socio-economically discriminating policies toward admissions even in its original years (Wilson, 2007, p. 5). It has always been a progressive institution and decided to accentuate social mobility, social obligation, student achievement, and building stronger undergraduate programs to make up for what it could not offer in terms of the collegiate ideal and the advancement of knowledge through university-level research. The progressivity of Amherst's admissions policies was articulated by popular Amherst President Alexander Meiklejohn during a speech in front of Calvin Coolidge. Meiklejohn spoke out against an Anglo-Saxon racial aristocracy and urged Amherst students and alumni to welcome ethnic Americans in to the nation's colleges, he said: "We dare not shut our gate to our fellow-citizens nor to their influence...And if they do not come, we must go out and bring them in” (Levine, 1988, p. 160). Amherst was decidedly ahead of its time in terms of open-minded admissions policies. But then again, Amherst maintained progressive stances throughout its history as we have seen in its creation of a 
charity fund and in student affairs issues related to student governance. The meritocratic and pluralistic vision espoused by Meiklejohn would not become a standard view in higher education for several years. By the end of this generation, democratic access triumphed over social exclusivity and the ascendancy of the academic curriculum confirmed the academic revolution in generation 9 (Geiger, 2005, p. 61).

\subsection{Generation 9}

Generation 9, which encompassed 1945 to 1975, was marked by expansion, academic standardization, the GI Bill, and the process by which the theoretical and specialized academic outlook of graduate schools was conveyed through the institutional order. This generation included the most expansive period in American higher education as college attendance tripled from 15 to 45 percent; the 1960s alone registered the largest percentage growth of any decade (Geiger, 2005, p. 61). During this time, institutions became more alike in terms of curricular offerings and administrative practices. The GI Bill encouraged ex-GIs to enroll in college in unprecedented numbers which overcrowded schools and often lowered academic standards. Federally sponsored research blossomed during these years. Theoretical and specialized knowledge permeated all levels and departments of higher education as newly minted PhDs staffed expanding universities (Geiger, 2005, p. 63). During this time, Amherst expanded its course offerings to include the famous "new curriculum" of required courses. This curriculum lasted for 20 years and provided a general education during the first two years and a period of more extensive work in one field in the final two years; this was achieved in the requirement of full-year courses in science, history, and English (Amherst College). In the late 60s the college introduced another curricular formation that recognized students' ability to tailor their own programs around basic distribution requirements (Amherst College). These curricular reforms were in line with the academic standardization movements of the era. While standardization brought stability in some regards, a new wave of the “collegiate way" would cause student unrest.

Unfortunately, as evidenced in previous generations, new forms of collegiate paternalism stifled students during this generation and a plethora of student riots and rebellions ensued. The student left on college campuses was energized to fight social injustice in all its perceived formations (racial inequality, socio-economic inequality, the Vietnam War, Free Speech infringements etc.). The Free Speech Movement at Berkeley and instances at other major universities such as Columbia generally increased student radicalism and militancy and checked the momentum of the academic revolution (Geiger, 2005, p. 63). The new left eventually burned out as their ideologies were more rigid than the doctrines they opposed; attempts at achieving a more humane society were circumvented by ideological extremism (Geiger, 2011, p. 2). The aftermath of the revolution ushered in a Manichaean view of the world for the New Left as it became the Academic Left; there were no gray areas in terms of being socially right or wrong (Geiger, 2011, pp. 26-27). Universities (or limited parts of universities) became locations for the critical examination of society and fight for social justice during the 70s but in the following decade, science and engineering began to cultivate advanced industrial relations and the intellectual activities of the Academic Left were confined to universities and directed inward (Geiger, 2011, pp. 30-31). The idea that higher 
education was integral to the national interest grew during this time. The Truman Commission Report pointed out the inequities and injustice of discrimination in higher education on the basis of income and race (Thelin, 2011, p. 269). The government's desire to support educational expansion would assist mass higher education while also stimulating advanced research and development in the sciences.

Amherst was not untouched by the anti-war, anti-inequality movement. In 1969 student grievances over the Vietnam War, race relations, and stifling college paternalism led to student plans to take over a college building. Advance warning of these plans allowed an ad hoc committee of students to request a two-day suspension of classes to allow for a college-wide discussion of campus and national concerns; this two-day period came to be known as the "moratorium" (Amherst College). Also during this generation at Amherst a Black Studies Department was established, the nation's first undergraduate program in neuroscience was established, and Anita Cilderman, a transfer student from Mount Holyoke, became the first woman to graduate from the college in 1976 (Amherst College). The enrollment of females within the college was a particularly important milestone as the climate for women continued to improve on campus with the abolition of fraternities, the fine-tuning of the disciplinary process, and an increase in women faculty members and ethnic diversity (Wilson, 2007, p. 276). New programs and departments can be viewed as attempts to couch critical examination of society and as increased efforts to provide curricular offerings that would be attractive to graduate and professional school admissions committees. As society moved toward mass education and big university expansion, small liberal arts colleges such as Amherst became increasingly resourceful in order to remain financially stable. For example, need-based financial aid policies were combined with need-blind admissions; this movement helped smaller college recruit talent across the nation and across the socio-economic spectrum (Thelin, 2011, p. 293). Amherst became exceptionally selective in terms of admission, reasonably affordable, and an attractive credential to research university doctoral programs. Small, selective colleges made an inordinate contribution to the education and development of scientific talent at the undergraduate level (Thelin, 2011, p. 295). Generally speaking, Amherst was an attractive option to large and impersonal university environments; smallness was a virtue.

\subsection{Generation 10}

Generation 10, from the mid-1970s until the current era, was marked by regulation and social relevance in higher education. In terms of regulation, the federal government investment in higher education increased significantly as evidenced by amendments to the Higher Education Act (HEA) in 1972 which provided aid to students on the basis of financial need via Pell Grants; in the 1980s this support would shift to guaranteed student loans (Geiger, 2005, p. 64). HEA amendments also ushered in Title IX legislation to assist minorities and women in pursuing college degrees. Student rebellion in the 60s set the stage for a continued pursuit of social relevance in the current generation. Universities further attempted to address social problems relating to the environment, war, and racial and socio-economic inequality. At Amherst, a Department of Law, Jurisprudence, and Social Thought was established to increase the school's focus on social justice; a Department of Women's and Gender Studies 
was created to further promulgate the study of gender inequalities on campus (Amherst College). In addition, relevance pursuits steered students away from the arts and sciences and more toward business aspirations. Colleges focused on providing students the skills necessary to survive in the workplace as a college credential was universally understood as a ticket to social mobility.

These regulatory advances in higher education were high points in what Geiger (2010) calls "the dismal 70s." After a turbulent previous decade the 70s were noted by a poor job market, alienation from academic culture, decreases in alumni gifts and research funding, and general financial hardship, higher education growth stagnated (Geiger, 2010, p. 1). The 80s brought a financial revolution for colleges via privatization. High tuition at private colleges such as Amherst signaled elite status to upper-middle-class students and families. A high-tuition, high aid culture was established on campus and selectivity increased even further as a revival of elitism meant that attracting more top students would boost quality throughout the school (Geiger, 2010, p. 3). In essence, prestige helped optimize tuition revenues. Overall, trends in financial aid, admissions selectivity, vocationalism, and research bottlenecked into the creation of two distinct current sectors in higher education, namely, selective and non-selective sectors. As Geiger (2010) points out, the non-selective institutions cater more often to lower-middle class part-time students and the selective sector offers high cost/high quality education to the most talented and affluent students (p. 6). This academic bifurcation subsumes a widening college attainment gap between groups along racial and socio-economic lines; this gap will continue to grow if the US maintains a disinvestment stance in relation to the non-selective sector. Highly selective and prestigious colleges such as Amherst continue to academically embody tenets of multiculturalism, internationalization, environmentalism, and civic engagement (a "modern quadrivium") that are less present in the non-selective sector (Geiger, 2010, p. 8). This socio-cultural content pervades Amherst today. As non-traditional student participation in higher education increases, the non-selective sector (particularly for-profit colleges and community colleges) will need to play a prominent role in higher education. An increased federal and state investment in higher education will be the only tangible way to increase the proportion of college graduates in America. Amherst will continue to thrive as an elite college with a focus on teaching undergraduates and a strong reputation for providing a high quality liberal arts education and sending graduates to prominent graduate and professional schools. Indeed, Amherst's endowment and popularity show little signs of waning and the school will continue to be a flag-bearer in liberal arts education.

\section{Conclusion}

In conclusion, a contextualization of the developments and landmarks of Amherst College within Roger Geiger’s “Ten Generations of American Higher Education” has been put forth. If we generally look at Amherst in comparison to broader inter-generational higher educational developments, themes of progressivity and persistence emerge. Amherst faced formidable struggles in relation to its founding, chartering, development, place within the changing higher education landscape, competing social, political, and ideological movements but the college met these challenges with resounding and resilient open-mindedness and 
progressive thinking. This progressivity has shown itself within aspects of galvanizing discursive support networks to found the school, student financial aid policies, admissions policies, and a general open-minded position toward the education of all students of all racial and socio-economic stations. In its incubatory years Amherst transcended and rebuffed the traditional view that CDCs were unpopular and impractical by steadily increasing enrollment and serving local religious and secular needs. In the face of daunting university proliferation, Amherst held fast to its liberal arts values, curriculum, and a strong sense of community and in turn, a credential from the college has become increasingly valued by graduate schools and society in general. Indeed through the generations Amherst thrived and evolved because it maintained President Meiklejohn's conception of “liberal:” “The instruction is dominated by no special interest, is limited to no single human task, but is intended to take human activity as a whole, to understand human endeavors not to their isolation but in their relations to one another and to the total experience which we call the life of our people" (Amherst College). Amherst grew on its own terms within its own unique and progressive brand of liberal education.

\section{Acknowledgement}

This research was inspired by Dr. Nathan Sorber at West Virginia University.

\section{References}

Allen, N. (1869). Physical culture in Amherst College. Lowell: Stone and Huse.

Amherst College (n.d.). A history of Amherst College. Retrieved from https://www.amherst.edu/aboutamherst/history

Ball, W.A. (1896). Amherst life: Selections from the undergraduate publications at Amherst College. Amherst: William Carpenter Howland.

Cutting, G.R. (1871). Student life at Amherst College. Carlisle: Applewood Books

Geiger, R.L. (2010, July). Postmortem for the current era: Change in American higher education, 1980-2010. In Ellen Lagemann and Harry Lewis, eds., For Whom and For What? The Future of U.S. Higher Education in a New Age of Scarcity, (publication pending).

Geiger, R.L. (2011, December). American universities and the student protest in the 1968 era: Causes and consequences. Paper presented at the Institutional and Academic Transformations in the 1968 Era conference, Universitá di Pisa, Pisa, (pp. 1-32).

Geiger, R.L. (Ed.). (2000). The American college in the nineteenth century. Nashville: Vanderbilt University Press.

Geiger, R.L. (2005). “The Ten Generations of American Higher Education” in R. O. Berdahl, P.G. Altbach, and P. J. Gumport, eds. Higher Education in the Twenty-First Century. $2^{\text {nd }}$ Edition. Baltimore: Johns Hopkins University Press, 38-70.

Hall, P.D. (1982). Noah Porter writ large? Reflections on the modernization of American Education and its critics, 1866-1916. In R. L. Geiger (Ed.), The American college in the 
nineteenth century (pp. 196-220). Nashville, TN: Vanderbilt University Press.

Hitchcock, E. (1863). Reminiscences of Amherst College: Historical, scientific, biographical, and autobiographical. Northampton: Bridgman and Childs.

Levine, D.O. (1988). The American college and the culture of aspiration, 1915-1940. Ithaca: Cornell University Press.

Potts, D.P. (1981). Curriculum and enrollment: Assessing the popularity of antebellum colleges. In R. L. Geiger (Ed.), The American College in the Nineteenth Century (pp. 37-45). Nashville: Vanderbilt University Press.

Rudolph, F. (1991). The American college and university: A history. Athens: University of Georgia Press.

Sorber, N.M. (2013). Creating colleges of science, industry, and national advancement: The origins of New England land-grant education. Perspectives on the History of Higher Education, 1-24.

Thelin, J.R. (2011). A history of American higher education. Baltimore: Johns Hopkins University Press.

Turner, J., \& Bernard, P. (1993). The German model and the graduate school: The University of Michigan and the origin myth of the American university. In R. L. Geiger (Ed.), The American college in the nineteenth century (pp. 221-241). Nashville, TN: Vanderbilt University Press.

Tyler, W.S. (1873). History of Amherst College during its first half century, 1821-1871. Springfield: Clark W. Bryan and Company.

Wilson, D.C. (2007). Passages of time: Narratives in the history of Amherst College. Amherst: Amherst College Press.

Wood, G.S. (1993). The radicalism of the American Revolution. New York: Vintage.

\section{Copyright Disclaimer}

Copyright reserved by the author(s).

This article is an open-access article distributed under the terms and conditions of the Creative Commons Attribution license (http://creativecommons.org/licenses/by/3.0/). 